\title{
An Assessment of Ethnomedicinal Use, Chemical Constituents Analysis and Bioactivity Evaluation on High Altitude Medicinal Plant Delphinium brunonianum of Manang District
}

\author{
Hari P. Tripathee, Ram P. Sharma 1 , Yagna P. Timilsina, Ramayan Pathak ${ }_{2}$ and \\ Krishna P. Devkota1 \\ IInstitute of Forestry, Tribhuvan University, Pokhara Campus, Pokhara \\ 2Institute of Forestry, Tribhuvan University, Hetauda Campus, Hetauda \\ e-mail:devkotakpd@yahoo.com
}

\begin{abstract}
The medicinal plant Delphenium brunonianum collected from Manang district, Nepal has been selected for its study on ethnomedicinal uses, phytochemical investigation and bioactivity evaluation. This plant is found to be used extensively by the community for the treatment of fever, headache, stomachache and poison removal. From phytochemical investigation, four known compounds namely $\beta$-amyrin (1), $\beta$-sitosterol (2), $\beta$-sitosterol glucoside (3) and anthriscifoldine (4) have been isolated from methanol extract of D. brunonianum. Compound $\mathbf{1}$ is triterpene, $\mathbf{2}$ and $\mathbf{3}$ are sterols, whereas, $\mathbf{4}$ is a diterpenoid alkaloid. The structures of all compounds were determined with modern spectroscopic techniques including 1D- and 2D- Nuclear Magnetic Resonance techniques and comparison with literature data. The extract and all compounds exhibited antibacterial properties with respect to the zone of inhibition and minimum inhibitory concentration against Bacillus subtilis, staphylococcus aureus, Pseudomonas aureginous, Escherchia coli and Salmonella flexinarie. Compound $\mathbf{4}$ was found to be more active than other compounds, and even than the standards ampicillin and gentamicin in most of the tested bacteria.
\end{abstract}

Key words: Delphenium brunonianum, phytochemical investigation, spectroscopic tools, antibacterial property, zone of inhibition

\section{Introduction}

Plants have been used as medicines from time immemorial. Early men relied on plants for food, medicine, clothing and shelter. Natural products, since the very beginning, have served as a template for the development of many important classes of drugs (Swain, 1972). Plants are remarkable in their ability to produce a vast array of diverse metabolites varying in structural complexity and biological activity. Plants continue to retain their historical significance as an important source of novel compounds, useful directly as medicinal agents, as model compounds for synthetic or semi-synthetic structure modifications and optimization, and as biochemical and pharmacological probes (Balandrin et al. 1993). Today, natural products and their derivatives still represent over $50 \%$ of all drugs in clinical use, with higher plant-derived natural products representing $c a .25 \%$ of the total. It has been reported that about a quarter of all the prescription drugs from community pharmacies in the world still contain plant extracts or active principles of plant origin (Rahman and Choudhary, 2001). Most of the wild floras of Nepal are rich in medicinal and aromatic properties like antibacterial, 
antiviral, antihelminitic, anticancer, sedative, laxative, cardiotonic, diuretic and others. They are important sources of bio-molecules, with application for the manufacture of pharmaceuticals and cosmeceuticals (Heinrich \& Gibbons 2001).

Delphinium is a genus of about 300 species of perennial flowering plants. Several phytochemical studies have been conducted in the genus Delphenium and more than 200 diterpenoid alkaloidal compounds have so far been isolated. Several new C(19)-diterpenoid alkaloids such as anthriscifoldines A-C, nudicaulamine, delbruninol, blacknine, winkleriline etc. and C(18)-diterpenoid alkaloids such as anthriscifolcines $\mathrm{F}$ and $\mathrm{G}$ etc. were obtained from different Delphinium species (Song et al., 2009). Their structures were elucidated based on the interpretation of NMR and high-resolution ESI MS data, and chemical transformation

A large number of high altitude medicinal plants are available at Manang district, out of which Delphinium brunonianum is one of the most popularly used herb for the treatment of different ailments. This herb is not only popular among the communities of the district, but also have great demand throughout Nepal and have good international market as well. It is distributed in Pamir, Afghanistan, the Himalayan region (Kashmir to Nepal) and South East Tibet at the altitude range of 3500 to $6000 \mathrm{~m}$ (Ghimire 1999). Exploration of ethnomedicinal uses, chemical constituent analysis and biological activity on such important medicinal herb in institutional level is very important.

Evaluation of biological activity on medicinal plants have important role on discovery of rational drugs. Based upon the traditional uses of the plant and its utilization pattern by the communities, different biological assays used to be conducted to justify the ethnomedicinal uses by scientific investigation. Out of several bench-top bioassays, antibacterial activity evaluation is one of the important assays which deal about the ability of medicinal plant to inhibit different bacteria. Based upon the ethnomedicinal uses of $D$. brunonianum by the communities of Manang on different bacterial infections and availability of bacteria on Western Regional Hospital (WRH), Pokhara, some common pathogenic bacteria such as Escherchia coli, staphylococcus aureus,
Pseudomonas aureginous, Salmonella flexinarie and Bacillus subtilis were used to test the antimicrobial activity of $D$. brunonianum.

\section{Methodology \\ General site survey}

All the D. brunonianum richness area of Manang district was identified through the help of official records of DFO, Manang and reconnaissance survey of concern VDCs of the district. From the general site survey, Alukharka of Dharapani VDC which is rich in D. brunonianum was selected.

\section{Social data collection}

For social data collection, semi-structured questionnaire household survey and published and unpublished secondary data was applied to gather the indigenous knowledge of $D$. brunonianum in the selected sites.

\section{Collection of plant material, shade drying and grinding}

The rhizome of $D$. brunonianum was collected during the field visit of Manang District. It was chopped in to small pieces and shade dried until the moisture content removed from the pieces. It was then ground into fine powder for extraction.

\section{Preparation of herbarium}

Herbarium specimen was prepared following standard botanical procedure for D. brunonianum. The herbarium was identified by Prof. Dr. Krishna Kumar Shrestha, Department Head, Central Department of Botany, Kirtipur and deposited at the same Department.

\section{General experimental conditions}

Melting points were determined on a Yanaco MP-S3 micro melting point apparatus and are uncorrected. Specific rotation $[\alpha]_{\mathrm{D}}\left(\mathrm{CHCl}_{3}, c\right.$ in $\left.\mathrm{g} / \mathrm{mL}\right)$ was determined by using a JASCO digital polarimeter (model DIP-3600). Infrared spectra were recorded on a JASCO FT/IR-410 spectrophotometer. UV spectra were measured on a Spectronic Unicam spectrophotometer. HRESI MS were recorded on a APEX III (Bruker Daltonik) 7 Tesla (ESI-FT-ICRMS). EI-MS spectra were recorded on a Finnigan MAT 95 spectrometer $(70 \mathrm{eV})$ with perfluorkerosene as the reference substance for 
Hari P. Tripathee et al./An Assessment of Ethnomedicinal.....

HREI MS. The ${ }_{1} \mathrm{H}$ and ${ }_{13} \mathrm{C}$ NMR spectra were recorded at $500 \mathrm{MHz}$ and $125 \mathrm{MHz}$, respectively, on a Bruker AMX 500 NMR spectrometer. Methyl, methylene and methine carbons were distinguished by DEPT experiments. Chemical shifts were reported in $\delta$ (ppm) using TMS as internal standard and coupling constants $(\mathrm{J})$ were measured in $\mathrm{Hz}$.

Column chromatography was performed on a column (silica gel 60, 70-230 and 240-300 mesh sizes, E. Merck). Pre-coated silica gel TLC plates (E. Merck, $\mathrm{F}_{254}$ ) were used to check the purity of compounds. TLC plates were viewed under ultraviolet light at 254 $\mathrm{nm}$ for fluorescence quenching spots and at $366 \mathrm{~nm}$ for fluorescent spots. Ceric sulfate and Dragendorff's spraying reagents were used for the staining of non alkaloidal and alkaloidal compounds, respectively on TLC.

\section{Extraction, fractionation and isolation of compounds}

The powdered rhizome (500 g) was extracted with methanol by using the Soxhlet apparatus. The extract was concentrated under vacuum by using rotatory evaporator to obtain the crude extract (56 g), which was then dissolved in methanol (Scheme-1). The methanol soluble fraction $(53.0 \mathrm{~g})$ was subjected to a column chromatography on silica gel and eluted with a gradient system of pet. ether, chloroform and methanol, which yielded eight major fractions (S1S8).

The fraction S4 (2.2 g), obtained on elution with 40\% chloroform/pet. ether was loaded on to a flash silica gel column. It was eluted with $35 \%$ chloroform $/ 65 \%$ pet. ether to yield two major sub-fractions (1S4, and 2S4). Elution of the sub-fraction $2 \mathrm{~S} 4(250.5 \mathrm{mg})$ with $40 \%$ dichloromethane $/ 60 \%$ pet. ether yielded compound $1(60.5 \mathrm{mg})$. The fraction S7 (1.8 g) on elution with $5 \%$ methanol $/ 95 \%$ chloroform on a flash column chromatography over silica gel yielded compounds 2 (40.2 mg) and 3 (20.2 mg). Similarly, the fraction S6 $(1.2 \mathrm{~g})$ when eluted with $1 \%$ methanol/99\% chloroform on a flash chromatography over silica gel yielded compound 4 (17.2 mg).

\section{$\beta$-Amyrin (1)}

Colorless needle shaped crystals, $R_{\mathrm{f}}: 0.44\left(\mathrm{CHCl}_{3} /\right.$ pet. ether in 60:40), M. P.: 188-190 ${ }^{\circ} \mathrm{C}$ [Reported 193$\left.195^{\circ} \mathrm{C}\right],[\alpha]_{\mathrm{D} 25}: 103^{\circ}(c=0.06, \mathrm{MeOH})$ [Reported $88^{\circ}$ $\left.\left(\mathrm{CHCl}_{3}\right)\right]$, IR $\left(\mathrm{CHCl}_{3}\right) v_{\max } \mathrm{cm}_{-1}: 3150(\mathrm{OH}), 1663$ $(\mathrm{C}=\mathrm{C})$, EI MS $m / z$ (rel. int. \%): $426\left(\mathrm{M}_{+}, 63\right), 411$ (16), 408 (6), 393 (8), 218 (100), 207 (16), 203 (32), 191 (17), 189 (59), 175 (15), 161 (11), 135 (30), 133 (15), 123 (17), 121 (27), 119 (14), HREI MS m/z :
426.3854 (calcd for $\mathrm{C}_{30} \mathrm{H}_{50} \mathrm{O}, 426.3861$ ), ${ }_{1} \mathrm{H}-\mathrm{NMR}, \delta$ $\left(\mathrm{CDCl}_{3}, 500 \mathrm{~Hz}\right): 0.74(3 \mathrm{H}, \mathrm{s}, \mathrm{Me}-24), 0.77(3 \mathrm{H}, \mathrm{s}$, Me-28), 0.83 (3H, s, Me-25), 0.92 (3H, s, Me-23), 0.95 (6H, s, Me-29, Me-30), 0.97 (3H, s, Me-26), 1.02 (3H, s, Me-27), 3.22 (1H, m, H-3), 5.24 (1H, br $\left.\mathrm{d}, J_{12,11}=6.3 \mathrm{~Hz}, \mathrm{H}-12\right)$.

\section{B-Sitosterol (2)}

White amorphous solid, $\mathrm{R}_{\mathrm{f}}: 0.53\left(\mathrm{MeOH} / \mathrm{CHCl}_{3}\right.$ in 8:92), M. P.: $142-144^{\circ} \mathrm{C}$ [Reported $142-144^{\circ} \mathrm{C}$ ], IR $\left(\mathrm{CHCl}_{3}\right) v_{\max } \mathrm{cm}_{-1}: 3402(\mathrm{OH}), 2901(\mathrm{CH})$, EI MS m/z (rel. int. \%): $414\left(\mathrm{M}_{+}, 100\right), 399$ (15), 329 (19), 303 925), 273 (20), 213 (18), 95 (21), HREI MS: $m / z$ 414.3857 (calcd for $\mathrm{C}_{29} \mathrm{H}_{50} \mathrm{O}, 414.3850$ ), ${ }_{1} \mathrm{H}-\mathrm{NMR}, \delta$ (500 MHz, $\left.\mathrm{CDCl}_{3}\right): 0.65$ (3H, s, Me-18), 0.79 (3H, d, $\left.J_{27,25}=6.8 \mathrm{~Hz}, \mathrm{Me}-27\right), 0.82\left(3 \mathrm{H}, \mathrm{t}, J_{29,28}=7.0 \mathrm{~Hz}\right.$, Me-29), $0.83\left(3 \mathrm{H}, \mathrm{d}, J_{26,25}=6.8 \mathrm{~Hz}, \mathrm{Me}-26\right), 0.90$ $\left(3 \mathrm{H}, \mathrm{d}, J_{21,20}=6.2 \mathrm{~Hz}, \mathrm{Me}-21\right), 0.98(3 \mathrm{H}, \mathrm{s}, \mathrm{Me}-19)$, $3.51(1 \mathrm{H}, \mathrm{m}, \mathrm{H}-3), 5.33$ (1H, m, H-6).

\section{B-Sitosterol glucoside (3)}

Colorless needle shaped crystals, $R_{\mathrm{f}}: 0.48(\mathrm{MeOH} /$ $\mathrm{CHCl}_{3}$ in 12:88), M. P.: 273-274 ${ }^{\circ} \mathrm{C}$ [Reported 270$272^{\circ} \mathrm{C}$ ], IR $\left(\mathrm{CHCl}_{3}\right) v_{\max } \mathrm{cm}_{-1}: 3400(\mathrm{OH}), 2893(\mathrm{CH})$, $1630(\mathrm{C}=\mathrm{C})$, EI MS m/z (rel. int. \%): $414\left(\mathrm{M}_{+}, 100\right)$, 399 (15), 329 (19), 303 (25), 273 (20), 213 (18), 95 (21), FAB MS: $m / z 573(\mathrm{M}-\mathrm{H})+{ }_{1} \mathrm{H}-\mathrm{NMR}, \delta(500$ $\left.\mathrm{MHz}, \mathrm{CDCl}_{3}+\mathrm{MeOD}\right): 0.67\left(3 \mathrm{H}, \mathrm{d}, J_{27,25}=6.4 \mathrm{~Hz}\right.$, Me-27), 0.69 (3H, t, $\left.J_{29,28}=6.6 \mathrm{~Hz}, \mathrm{Me}-29\right), 0.71(3 \mathrm{H}$, s, Me-18), $0.73\left(3 \mathrm{H}, \mathrm{d}, J_{26,25}=6.8 \mathrm{~Hz}, \mathrm{Me}-26\right), 0.80$ $\left(3 \mathrm{H}, \mathrm{d}, J_{21,20}=6.3 \mathrm{~Hz}, \mathrm{Me}-21\right), 0.87(3 \mathrm{H}, \mathrm{s}, \mathrm{Me}-19)$, $3.43(1 \mathrm{H}, \mathrm{m}, \mathrm{H}-3), 4.28$ (d, $\left.J_{1^{\prime}, 2^{\prime}}=7.7 \mathrm{~Hz}, \mathrm{H}-1^{\prime}\right), 5.24$ (1H, m, H-6).

\section{Anthriscifoldine C (4)}

White amorphous powder, $R_{\mathrm{f}}$ : 0.48 $\left(\mathrm{MeOH} / \mathrm{CHCl}_{3} / \mathrm{DEA}\right.$ in 12:87:1), IR (KBr) $\nu_{\max } \mathrm{cm}_{-1}$ : 3387, 2872, 1740, 1245, 1087, HR ESI MS $m / z$ : 492.2940 $[\mathrm{M}+\mathrm{H}]_{+}$, Calcd for $\mathrm{C}_{27} \mathrm{H}_{42} \mathrm{NO}_{7}, 492.2961$, ${ }_{1} \mathrm{H}-\mathrm{NMR}, \delta\left(500 \mathrm{MHz}, \mathrm{CDCl}_{3}\right): 1.04(3 \mathrm{H}, \mathrm{t}, J=7.2$ $\mathrm{Hz}, \mathrm{H}-22), 2.09$ (3H, s, OAc), 3.13, 3.07 (ABq, $J=$ $8.8 \mathrm{~Hz}, \mathrm{H}-18$ ), 3.36, 3.26, 3.25 (each $3 \mathrm{H}, \mathrm{s}, 3 \mathrm{x}$ $\left.\mathrm{OCH}_{3}\right), 4.85$ (1H, t, $\left.J=4.8 \mathrm{~Hz}, \mathrm{H}-14 \mathrm{~b}\right), 5.01,4.94$ (each $\left.1 \mathrm{H}, \mathrm{s}, \mathrm{OCH}_{2} \mathrm{O}\right),{ }_{13} \mathrm{C}-\mathrm{NMR}, \delta(125 \mathrm{MHz}$, $\left.\mathrm{CDCl}_{3}\right): 83.5(\mathrm{C}-1), 26.1$ (C-2), $31.9(\mathrm{C}-3), 38.0$ (C4), 43.3 (C-5), 31.8 (C-6), 91.2 (C-7), 80.8 (C-8), 47.1 (C-9), 36.6 (C-10), 50.7 (C-11), 27.2 (C-12), 44.0 (C-13), 75.2 (C-14), 33.1 (C-15), 81.7 (C-16), 62.0 (C-17), 78.8 (C-18), 52.1 (C-19), 50.7 (C-21), $14.2(\mathrm{C}-22), 55.7\left(1-\mathrm{OCH}_{3}\right), 56.3\left(16-\mathrm{OCH}_{3}\right)$, 
$59.4\left(18-\mathrm{OCH}_{3}\right), 92.9\left(\mathrm{OCH}_{2} \mathrm{O}\right), 171.9(\mathrm{C}=\mathrm{O}$ of $\mathrm{OAc}), 21.2\left(\mathrm{CH}_{3}\right.$ of $\left.\mathrm{OAc}\right)$.

\section{Antibacterial assay}

Antimicrobial assay of extracts, fractions, subfractions and compounds was performed on different microbes such as Escherchia coli, staphylococcus aureus, Pseudomonas aureginous, Salmonella flexinarie and Bacillus subtilis with respect to the measurement of Zone of Inhibition (ZOI) and Minimum Inhibitory Concentration (MIC).

The ZOI and MIC values determination was performed as explained by Devkota et al. (2000) and Devkota and Dutta (2001). Briefly, ZOI was measured by agar well diffusion technique in which 6 $\mathrm{mm}$ diameter well was prepared in Muller Hinton Agar (MHA) plate containing inoculums of different bacteria. Appropriate concentration of extracts along with the standard drugs were added to the well and incubated at $37 \mathrm{U} C$ for 24 hours. The ZOI was the area on the plates where the growth of bacteria is inhibited by the plant extracts. Similarly, MIC value was determined by two fold serial dilution technique and incubated at 37 ÚC for 24 hours. The incubated material was then be swabbed to the MHA plates and result observed after 24 hours incubation at 37ÚC.

\section{Comparison with the action of antibiotics}

Whether the antimicrobial activity of medicinal plant is strong, moderate or weak can be find out by comparison between the effect of the plant extract or compounds and the standard drug on particular bacteria. For this, plant extract, compound and standard drug were tested for their zone of inhibition, to find out whether their antimicrobial activities were strong, weak or medium. The antibiotics selected during this study were ampicillin and gentamycin.

\section{Results and Discussion \\ Ethnomedicinal uses of $\boldsymbol{D}$. brunonianum}

The utilizing pattern of $D$. brunonianum by the community of Dharapani VDC of Manang district was acquired by using house hold survey and key informant interview. From the study, $D$. brunonianum was found to be popularly used by the community for the treatment of fever, headache, stomachache, cough and removal of poison. In case of fever and cough, the dry and powdered rhizome is taken with water, a teaspoonful twice in a day after taking food. When a person is suffering from stomachache, headache and poison, either the fresh rhizomes are chewed twice to thrice in a day or taken its powder by mixing with sugar and water twice in a day for 3-4 days.

The community of the study area was found to be happy to have different medicinal plants in their area and are able to cure diseases by using those plants. Previously, most of the community members weret involved to collect those valuable plants and marketted. But, now a days they are not involving in such activities, however, according to them, many people from other districts such as Gorkha, Lamjung and Kaski involved to collect those medicinal plants in illegal way. The community want to give message to policy makers of Governmental and Nongovernmental organization that there should be some program related to conservation of such valuable medicinal plants in their natural habitat.

\section{Phytochemical investigation of $D$. brunonianum}

The phytochemical investigation on secondary metabolites from the fractions of $D$. brunonianum yielded following four known compounds 1-4.

\section{$\beta$-Amyrin (1)}

Compound 1 was obtained as colorless needle shaped crystals. The HREI MS showed the M+peak at $\mathrm{m} / \mathrm{z}$ 426.3854 supporting the formula $\mathrm{C}_{30} \mathrm{H}_{50} \mathrm{O}$ (calcd 426.3861). The IR spectrum indicated the presence of hydroxyl $\left(3150 \quad \mathrm{~cm}_{-1}\right)$ and olefinic $\left(1663 \quad \mathrm{~cm}_{-1}\right)$ functionalities in compound $\mathbf{1}$.

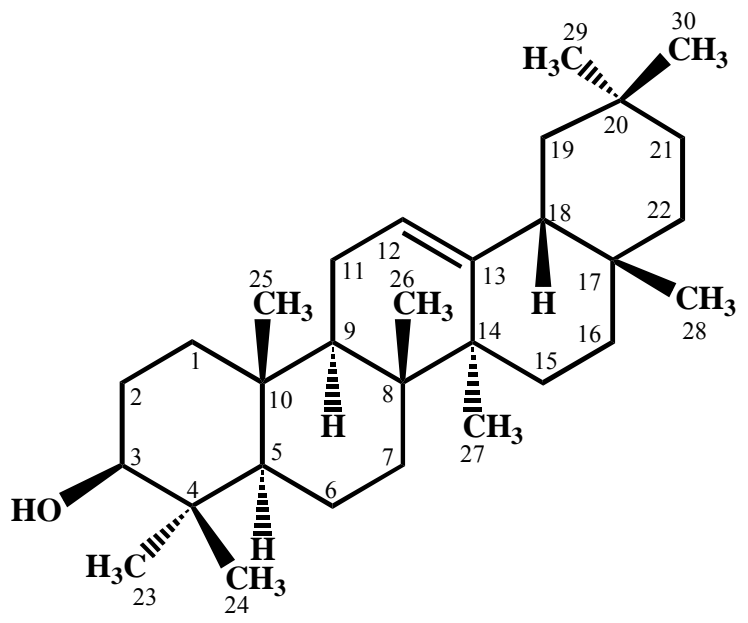

$\beta$-Amyrin (1) 
Hari P. Tripathee et al./An Assessment of Ethnomedicinal.....

The ${ }_{1} \mathrm{H}-\mathrm{NMR}$ spectrum of compound 1 showed upfield signals for eight tertiary methyl groups, characteristic of a triterpene skeleton (Bahuguna and Jangwan, 1987). A multiplet at $\delta 3.22$ was assigned to the $\mathrm{C}-3$ proton geminal to a hydroxyl group, while a broad doublet resonating at $\delta 5.24\left(J_{12,11}=6.3 \mathrm{~Hz}\right)$ was due to the $\mathrm{C}-12$ olefinic proton. The EI MS fragmentation was characteristic of an $\Delta_{12}-$ unsaturated oleanane type triterpenes, largely resulting from a retro-Diels-Alder's cleavage (Budzikiewicz et al., 1963).
The above spectral data was in agreement with the reported values for $\beta$-amyrin (Ulubelen and Topcu, 1987). This is the first report of its isolation from this plant, although this compound was previously obtained from several other plant species (Ahmad and Rahman, 1994).

\section{B-Sitosterol (2)}

Compound 2 was isolated as a white amorphous material. The HREI MS showed the molecular ion at $m / z 414.3857$ in agreement with the formula $\mathrm{C}_{29} \mathrm{H}_{50} \mathrm{O}$ (calcd 414.3850) corresponding to five degrees of unsaturation.

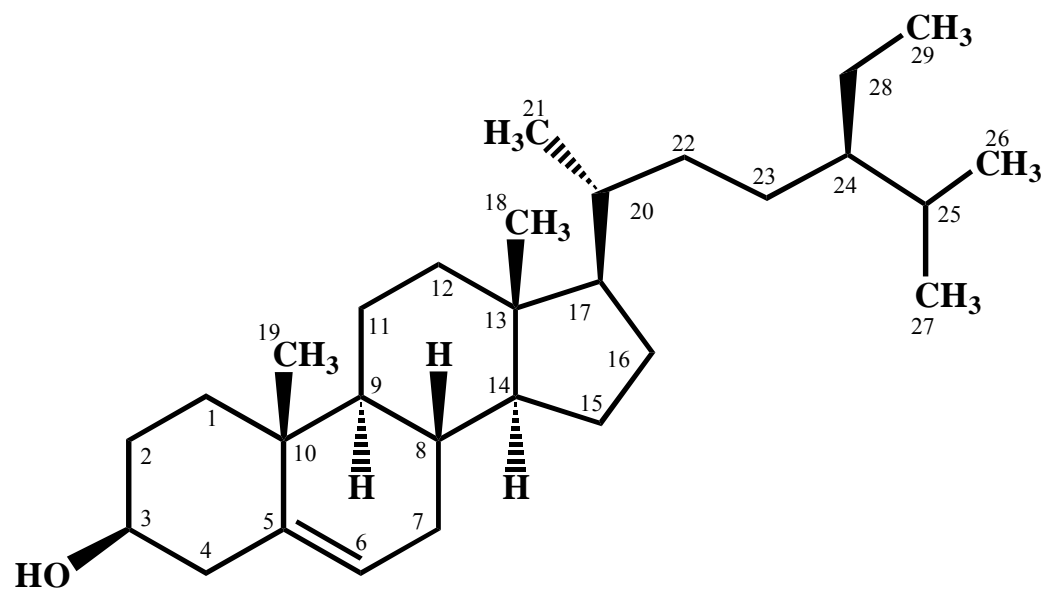

$\beta$-Sitosterol (2)

The ${ }_{1} \mathrm{H}-\mathrm{NMR}$ spectrum of compound $\mathbf{2}$ was characteristic of a steroidal system. Two singlets resonating at $\delta 0.65$ and 0.98 were due to the C-18 and C-19 quaternary methyl protons, respectively. Three doublets appearing at $\delta 0.90\left(\mathrm{~d}, J_{21,20}=6.2 \mathrm{~Hz}\right)$, $0.83\left(\mathrm{~d}, J_{26,25}=6.8 \mathrm{~Hz}\right)$ and $0.79\left(\mathrm{~d}, J_{27,25}=6.8 \mathrm{~Hz}\right)$ were due to C-21, C-26, and C-27 secondary methyl protons, respectively. A triplet at $\delta 0.82\left(J_{29,28}=7.0\right.$ $\mathrm{Hz})$ was due to the primary C-29 methyl protons. A multiplet resonating at $\delta 3.51$ was consistent with the $\mathrm{H}-3 \alpha$, geminal to the $3 \beta$-hydroxy functionality. A multiplet at $\delta 5.33$ was assigned to the $\mathrm{C}-6$ olefinic proton. A comparative study of its spectroscopy data with the literature revealed that compound $\mathbf{2}$ is the well known phytosterol $\beta$-sitosterol, previously isolated from a large number of plant species (Heble, 1967).

\section{B-Sitosterol glucoside (3)}

Compound $\mathbf{3}$ was isolated as a crystalline solid by column chromatography of the sub-fraction S7. The FAB MS (-ve) of 3 showed the molecular ion at $\mathrm{m} / \mathrm{z}$ 573. A comparative study of the spectroscopic data of compound 3 with the reported data revealed it to be $\beta$-sitosterol glucoside (Monaco and Previtera, 1984) which was further confirmed by TLC comparison with authentic sample. 


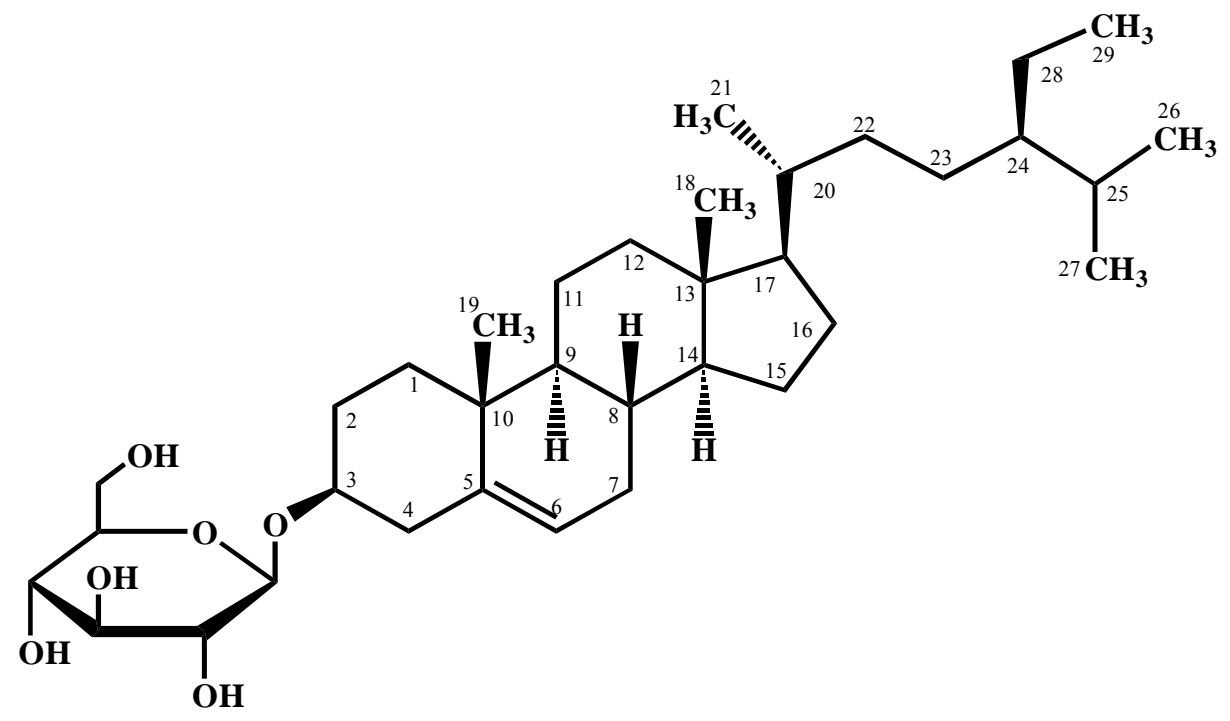

$\beta$-Sitosterol glucoside (3)

\section{Anthriscifoldine C (4)}

Compound 4 was isolated as a white amorphous material. The HR ESI MS showed the molecular ion at $\mathrm{m} / \mathrm{z} 492.2940[\mathrm{M}+\mathrm{H}]_{+}$in agreement with the formula $\mathrm{C}_{27} \mathrm{H}_{42} \mathrm{NO}_{7}$ (calcd 492.2961).

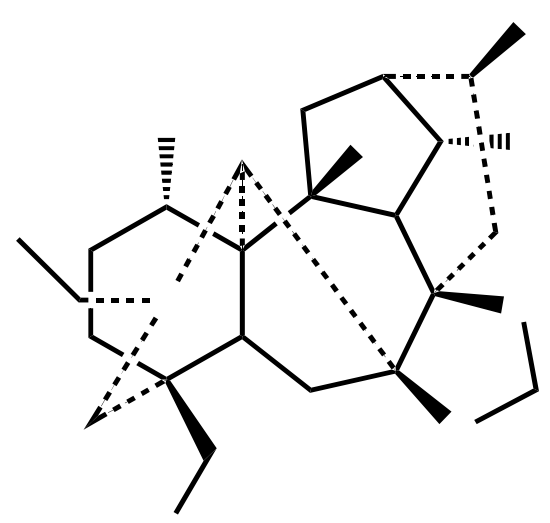

The detail study of ${ }_{1} \mathrm{H}-\mathrm{NMR}$ spectra in $\mathrm{CDCl}_{3}$ indicated compound 4 as a lycoctonine-type C19diterpenoid alkaloid. Its ${ }_{1} \mathrm{H}-$ and ${ }_{13} \mathrm{C}-\mathrm{NMR}$ data showed distinctive signals at $\delta_{\mathrm{H}} 1.02(3 \mathrm{H}, \mathrm{t}, J=7.2$
$\mathrm{Hz}$ ) and $\delta_{\mathrm{c}} 14.2$ for an $N$-ethyl group; $\delta_{\text {н }} 3.36,3.26$, 3.25 (each $3 \mathrm{H}, \mathrm{s}$ ) for three methoxy groups; $\delta_{\mathrm{H}} 4.93$, $5.01($ each $1 \mathrm{H}, \mathrm{s})$ and $\delta \mathrm{c} 92.9$ for a methylenedioxy group; and $\delta_{\text {н }} 2.09(3 \mathrm{H}, \mathrm{s})$ with $\delta \mathrm{c} 21.2 \mathrm{q}, 171.9 \mathrm{~s}$ for an acetoxy group. A comparative study of its spectroscopy data with the literature revealed that compound $\mathbf{4}$ is the well known compound, previously isolated from Delphenium species (Song et al. 2009) is the first report from $D$. brunonianum.

\section{Antibacterial activity evaluation of $D$. brunonianum}

During the research period, the antibacterial activity on crude extracts and compounds 1-4 that has been obtained from $D$. brunonianum was determined by measuring ZOI and MIC determination. The test organisms were B. subtilis, $S$. aureus, $P$. aureginosa, $E$. coli and $S$. flexinarie. The ZOI was measured by well diffusion method whereas MIC was determined by two fold serial dilution technique. The result of ZOI measurement is presented in Table 2. The extract and compounds displayed moderate to good antibacterial properties on the tested bacteria in which compound $\mathbf{4}$ showed comparatively higher activity than other compounds. The higher activity of compound $\mathbf{4}$ might be due to its alkaloidal nature as alkaloids shows diverse biological activities. 
Hari P. Tripathee et al./An Assessment of Ethnomedicinal.....

Table 2. ZOI of crude extract and compounds 1-4 from $D$. brunonianum

\begin{tabular}{llllll}
\hline $\begin{array}{l}\text { Extracts, fractions and } \\
\text { compounds }^{\mathrm{a}}\end{array}$ & \multicolumn{5}{c}{ ZOI $(\mathrm{mm})$} \\
\cline { 2 - 6 } & B. subtilis & S. aureus & P. aureginosa & E. coli & S. flexinarie \\
\hline Crude extract & 12.5 & 11.2 & 15.3 & 16.7 & 18.8 \\
$\mathbf{1}$ & 10.1 & 9.7 & 7.4 & 9.2 & 8.7 \\
$\mathbf{2}$ & 9.7 & 8.5 & 8.8 & 9.4 & 13.1 \\
$\mathbf{3}$ & 8.5 & 12.3 & 10.6 & 9.5 & 10.1 \\
$\mathbf{4}$ & 24.0 & 21.2 & 18.4 & 23.4 & 24.2 \\
Ampicillin $^{\text {b }}$ & 29.0 & 26.0 & n.t. & n.t. & n.t. \\
Gentamycin $^{\text {b }}$ & n.t. & n.t. & 29.0 & 31.0 & 27.0 \\
\hline${ }^{a}$ Tested at $100.0 \mathrm{mg} / \mathrm{mL}$ for extracts and fractions and $5.0 \mathrm{mg} / \mathrm{mL}$ for pure compounds. & & \\
${ }^{\mathrm{b} S t a n d a r d ~ d r u g s ~ i n ~ t h i s ~ a s s a y . ~}$ & & & &
\end{tabular}

The MIC value (Table 3) of compounds 1-3 was found to be less than standard drugs, whereas, compound 4 exhibited higher MIC value than the standard ampicillin on B. subtilis and S. aureus. Similarly, compound $\mathbf{4}$ also showed higher MIC values than the standard gentamicin against E. coli and $S$. flexinarie. The higher activity of compound 4 might be due to its alkaloidal nature as alkaloids shows diverse biological activities.

Table 3. Minimum inhibitory concentration values of compounds 1-4 from $D$. brunonianum

\begin{tabular}{|c|c|c|c|c|c|}
\hline \multirow[t]{2}{*}{ Compounds } & \multicolumn{5}{|c|}{$\mathrm{MIC}(\mu \mathrm{M})$} \\
\hline & B. subtilis & S. aureus & P. aureginosa & E. coli & S. flexinarie \\
\hline 1 & 405.4 & 405.4 & 308.4 & 512.4 & 424.5 \\
\hline 2 & 588.2 & 348.2 & 548.2 & 886.2 & 548.2 \\
\hline 3 & 446.8 & 358.4 & 446.8 & 646.4 & 358.4 \\
\hline 4 & 64.4 & 24.4 & 24.4 & 80.2 & 31.0 \\
\hline ampicillin $^{a}$ & 89.7 & 5.6 & n.t. ${ }^{b}$ & 179.4 & 89.7 \\
\hline gentamicin $^{a}$ & n.t. ${ }^{b}$ & n.t. ${ }^{b}$ & 5.2 & n.t. ${ }^{b}$ & n.t. ${ }^{b}$ \\
\hline
\end{tabular}

\section{Acknowledgements}

We would like to thanks ComForM Project, Institute of Forestry, Pokhara for financial support to conduct this research. Prof. Norbert Sewald of Bielefeld University, Gemany is highly acknowledged for measuring spectral data of pure compounds. The Microbiology Laboratory of Western Regional Hospital, Pokhara and the community members of Dharapani VDC of Manang District deserves special thanks. The extraction, fractionation and purification of compounds from $D$. brunonianum were done in Medicinal and Aromatic Plants Research Laboratory of the Institute of Forestry, Pokhara. This laboratory was established under the funding support of Alexander von Humboldt Foundation, Germany.

\section{References}

Ahmad, V.U. and A.A. Rahman. 1994. Hand book of natural product data: pentacyclic triterpenes. Elsevier Science B. V., Amsterdam, Vol. 2, pp.21.

Rahman, A.A. and M.I. Choudhary. 2001. Sharing Innovative Experiences. Third World Academy of Sciences, Italy, pp.8.

Bahuguna, R.P., and J.S. Jangwan. 1987. Constituents of Rhododendron barbatum. Journal of natural Products 50:309-338.

Balandrin, M.F., A.D. Kinghorn and N.R. Fransworth. 1993. Human medicinal agents from plants, American Chemical Society, Washington DC, pp.2.

Budzikiewicz, H., J.M. Wilson and C. Djerrasi. 1963. Mass spectrometry in structural and stereochemical problems. XXXII. pentacyclic triterpenes. Journal of American Chemical Society 85:3688-3695. 
Devkota, K.P. and I.C. Dutta. 2001. Antibacterial activities of commercially traded herbs used in traditional medicines in communities of Doti district, Nepal, Report submitted to IUCN, Kathmandu, Nepal.

Devkota, K.P., R. Acharya, M.P. Baral and R.P. Pokherel. 2000. Antimicrobial activity of some herbal plants used in traditional medicine in Nepal. Proceedings, Third National Conference on Science \& Technology, RONAST, Vol. II, pp.1311-1316.

Ghimire, S.K. 1999. Medicinal and aromatic plants in the Nepal Himalaya: status, use, sale and conservation. The Wildlife, 1:42.

Heble, M.R., S. Narayanaswami and M.S. Chadha. 1967. Diosgenin and beta-sitosterol: isolation from Solanum xanthocarpum tissue cultures. Science 161:1145.
Heinrich, M. and S. Gibbons. 2001. Ethnopharmacology in drug discovery: An analysis of its role and potential contributions. Journal of Pharmacy and Pharmacology 53:425-432.

Monaco, P. and L. Previtera. 1984. Isoprenoids from the leaves of Quercus suber. Journal of Natural Products 47:673-676.

Song, L., X.Y. Liu, Q.H. Chen and F.P. Wang. 2009. New C19- and C18-diterpenoid alkaloids from Delphinium anthriscifolium var. savatieri. Chemical and Pharmaceutical Bulletin 57:158-161.

Swain, T. 1972. Plants in the Development of Modern Medicines, Harvard University Press, Cambridge.

Ulubelen, A. and G. Topcu. 1987. Triterpenic and steroidal compounds from the roots of five Salvia species. Fitoterapia 58:205-206. 